\title{
Optimalisasi Pengelolaan Wakaf (Studi di Kabupaten Demak)
}

\author{
Riyanto
}

\begin{abstract}
Optimization of Wakaf Management (Study In Demak District). Waqf, as one of the Islamic social and economic institutions has enormous potentials in encouraging efforts to improve people's economy. As a country with a huge population and the Muslim majority, Indonesia needs to explore and develops the potential of this religious institution. The combination of religious orders and social values can be utilized as a strong ideological backdrop for the government in managing waqfs so as to grow and be productive. This study tries to examine the status of land endowed in wakaf in Demak district before and after the enactment of Waqaf Law Number 41/ 2004 as well as to identify factors supporting and hindering efforts to optimize wakaf empowerment. This research used a socio-normative approach and it was conducted in several locations within Demak Regency. This study reveals that wakaf institutions in Demak Regency have not been able to improve the welfare of the community. This is because a lot of wakaf land in the area are not managed professionally and productively. Therefore, in the future, it is necessary to develop the professionalism of the Nazir (curator) so that Wakaf institutions can be developed optimally and innovatively to achieve the prosperity of muslim society.
\end{abstract}

Keywords: waqf management, waqf institutions, welfare of the community, Demak

Abstrak: Optimalisasi Pengelolaan Wakaf (Studi di Kabupaten Demak). Wakaf, sebagai salah satu lembaga sosial dan ekonomi umat, memiliki potensi yang sangat besar dalam mendorong upaya peningkatan ekonomi umat. Sebagai suatu negara yang memiliki jumlah penduduk yang sangat besar dan mayoritas muslim, Indonesia perlu menggali dan mengembangkan potensi lembaga keagamaan ini. Kombinasi antara perintah agama dan nilai-nilai sosial dapat menjadi sandaran ideologis yang kuat bagi pemerintah dalam mengatur pengelolaaan wakaf agar makin berkembang dan produktif. Penelitian ini menelaah bagaimana kedudukan hukum tanah wakaf di kabupaten sebelum dan sesudah berlakunya Undang-Undang Nomor 41 Tahun 2004 Tentang Wakaf sekaligus mengidentifikasi faktorfaktor apa saja yang dapat mendukung dan menghambat upaya optimalisasi pemberdayaan wakaf. Penelitian ini menggunakan pendekatan sosio-normatif dan dilaksanakan di beberapa lokasi dalam wilayah Kabupaten Demak. Studi ini mengungkap fakta bahwa lembaga wakaf di Kabupaten Demak belum mampu meningkatkan kesejahteraan masyarakat. Hal ini dikarenakan banyak tanah-tanah wakaf di Kabupaten Demak tidak dikelola secara profesional dan kurang produktif. Untuk itu, ke depan dibutuhkan pembinaan profesionalitas para nazir agar lembaga wakaf dapat berkembang secara optimal dan inovatif sehingga kemakmuran masyarakat dapat terwujud secara merata.

Kata Kunci: manajemen wakaf, lembaga wakaf, kesejahteraan masyarakat, Demak

Dosen Sekolah Tinggi Agama Islam Pati

Jl. Kampus Raya No. 5 Pati

E-mail: riyantoahmad073@gmail.com 


\section{Pendahuluan}

Negara Republik Indonesia merupakan salah satu negara berkembang di dunia. Dalam hal ini laju pembangunan baik secara fisik maupun non fisik merupakan prioritas utama. Pembangunan non fisik berupa pembangunan manusia seutuhnya dengan tujuan utama terfokus pada kesejahteraan masyarakat secara keseluruhan, sedangkan pembangunan fisik berupa pembangunan sarana dan prasarana di segala bidang. Sebagai negara yang sedang giat-giatnya membangun, tentunya kebutuhan tempat untuk pengembangan merupakan problematika yang sangat mendasar. Terutama laju pertumbuhan penduduk yang sangat pesat menjadikan semakin terbatasnya tanah untuk pengembangan tersebut. Dalam hal ini maka masalah tanah menjadi hal yang sangat penting sekali. ${ }^{1}$ Karena proses pengembangan fisik tentunya membutuhkan lahan untuk pengembangan. Namun yang terpenting dalam proses pengembangan jangan mengenyampingkan tujuan utama pembangunan yaitu untuk meningkatkan kesejahteraan masyarakat, hal ini sesuai dengan tujuan Negara Kesatuan Republik Indonesia sebagaimana diamanatkan dalam Pembukaan Undang-Undang Dasar 1945 alinea keempat antara lain adalah untuk memajukan kesejahteraan umum. Untuk terwujudnya masyarakat yang sejahtera terutama peningkatan kesejahteraan umat Islam, maka sangatlah perlu menggali dan mengembangkan potensi-potensi yang terdapat di dalam lembaga keagamaan yang tidak hanya bersifat ubûdiyyah tetapi juga memiliki nilai ekonomis, sehingga terdapat dua manfaat yang bisa dirasakan oleh masyarakat muslim, yaitu manfaat yang bersifat $u k h r a w \hat{\imath}$ juga manfaat yang bersifat duniawî (sosial dan ekonomi).

${ }^{1}$ Terkait persoalan tanah, dapat dilihat selengkapnya dalam karya Koeswahyono, Imam. "Penyelesaian Persoalan Tanah Perkebunan dalam Perspektif Socio Legal (Studi Pada Beberapa Perkebunan di Jawa Timur)." Jurnal Hukum \& Pembangunan 38, no. 4 (2008): 525-555. M. Nasution. "Hutan dan Persoalan Tanah Ulayat." Roundtable Discussion on Indigenous Peoples' Property Rights held by the Indonesian Human Rights Commission 24 (1999). Joyo Winoto. "Reforma Agraria: Mandat Politik, Konstitusi dan Hukum dalam Rangka Mewujudkan Tanah untuk Keadilan dan Kesejahteraan Rakyat." Paper. Delivered in General Lecture in Gajah Mada University. Yogyakarta 22 (2007). Elita Rahmi. "Tarik Menarik Antara Desentralisasi dan Sentralisasi Kewenangan Pemerintah Daerah dalam Urusan Pertanahan.” Jurnal Hukum Ius Quia Iustum 16 (2009). Hardianto Djanggih, dan Salle Salle. "Aspek Hukum Pengadaan Tanah bagi Pelaksanaan Pembangunan untuk Kepentingan Umum.” Pandecta: Research Law Journal 12, no. 2 (2018). 
Keberadaan lembaga wakaf menjadi sangat strategis. Di samping sebagai salah satu aspek ajaran Islam yang berdimensi spiritual, wakaf juga merupakan ajaran yang menekankan pentingnya kesejahteraan ekonomi (dimensi sosial). ${ }^{2}$ hal ini sesuai dengan fungsi wakaf sebagaimana termaktub dalam pasal lima (5) Undang-Undang Nomor 41 Tahun 2004 Tentang wakaf yaitu "Wakaf berfungsi mewujudkan potensi dan manfaat ekonomis harta benda wakaf untuk kepentingan ibadah dan untuk memajukan kesejahteraan umum". ${ }^{3}$ Muatan dalam UU Wakaf tersebut adalah bahwa wakaf tidak hanya untuk kemaslahatan Islam atau muslim semata. Akan tetapi, untuk kesejaheraan umum karena keberlangsungan pelaksanaan wakaf di Indonesia yang multi-SARA (Suku, Agama, Ras, dan Antar-golongan). ${ }^{4}$ Di sini jelas tersurat bahwa wakaf bukan hanya berfungsi sebagai sarana ' ubûdiyyah saja tetapi juga sebagai sarana dalam bermuamalah.

Mendasar dari problema tersebut wakaf merupakan solusi alternatif bagi pengembangan yang ditujukan bagi kesejahteraan masyarakat. Dari data yang diketahui, tanah wakaf yang ada di desa maupun di kota sangat luas. Potensi yang demikian itu seharusnya dimanfaatkan sebaik-baiknya guna menunjang kemakmuran dan kesejahteraan umum sebagai tujuan pembangunan itu sendiri. ${ }^{5}$

Dalam sejarahnya, wakaf telah memainkan peranan yang sangat vital dalam pembangunan ekonomi masyarakat muslim. Meskipun pengalaman sejarah cukup panjang dalam pengelolaan wakaf, namun masih dijumpai berbagai kenyataan bahwa pengelolaan wakaf belum mencapai hasil yang diharapkan. Wakaf yang diharapkan dapat mensejahterakan masyarakat belum terwujud. ${ }^{6}$

${ }^{2}$ Departemen Agama, Paradigma Baru Wakaf di Indonesia, Ditbang Zakat dan Wakaf Dirjen Bimas Islam dan Gara Haji (Jakarta: Depag I, 2004), h. 1.

${ }^{3}$ Tim Redaksi Nuansa Aulia, Kompilasi Hukum Islam (Hukum Perkawinan, Kewarisan, dan Perwakafan) (Bandung: CV. NUANSA AULIA, 2008), h.116.

${ }^{4}$ Moh. Rosyid, "Peran Sertifikat Tanah Wakaf dalam Mengantsipasi Dinamika Zaman: Studi Kasus Madrasah Diniyah Muawanatul Muslimin di Kudus," Jurnal Ziswaf 3, No. 1 (Juni 2016): h. 107.

${ }_{5}^{5}$ Abdul Ghofur Anshori, Hukum dan Praktik Perwakafan di Indonesia, Cet. II (Yogyakarta: Pilar Media, 2006), h. 3.

${ }^{6}$ Ahmad Djalaludin, "Legitimasi Fiqih Bagi Obtimalisasi dan Pendayagunaan Wakaf", 
Sampai saat ini pengelolaan dan manajemen wakaf di Indonesia masih kurang maksimal. Sebagai akibatnya cukup banyak harta wakaf terlantar dalam pengelolaannya, bahkan ada harta wakaf yang hilang. ${ }^{7}$ Pada tataran realitanya tidak sedikit tanah wakaf yang terbengkalai dan tidak terurus, yang menyebabkan tanah tersebut tidak produktif atau bahkan tidak jelas keberadaannya. Sehingga fungsi dari wakaf sebagai wadah yang berdimensi sosial belum bisa terwujud. Hal ini dikarenakan tata kelola tanah tersebut masih minim dan di tangani oleh orang-orang yang kurang memahami dalam aturan wakaf. Maka sangat dibutuhkan tenaga-tenaga terampil dan profesional untuk mengelola dan mengembangkan wakaf agar bisa menjadi produktif dan implikasinya dapat dirasakan oleh masyarakat.

Salah satu langkah strategis untuk meningkatkan kesejahteraan umum, maka dipandang sangat perlu meningkatkan peran wakaf sebagai salah satu Lembaga Sosial Islam yang sangat strategis dan potensial untuk dikembangkan. Karena wakaf tidak hanya mempunyai kontribusi ukhrowi (hablum minallah) saja bagi manusia, tetapi juga mempunyai kontribusi solutif bagi persoalan ekonomi masyarakat, hal ini sesuai dengan fungsinya yaitu untuk memajukan kesejahteraan umum. Di negara Indonesia lembaga ini merupakan penunjang utama dalam perkembangan masyarakat sebagai salah satu sarana guna pengembangan kehidupan keagamaan, khususnya umat yang beragama Islam dalam rangka mencapai kesejahteraan spiritual dan material menuju masyarakat adil makmur berdasarkan Pancasila. Maka sudah seharusnya potensi sosial ekonomi yang ada dalam wakaf harus digali dan dikembangkan untuk mewujudkan tujuan tersebut. Karena kenyataannya hampir setiap rumah ibadah, tempat-tempat pemakaman, lembaga-lembaga keagamaan, Perguruan Tinggi Islam semuanya dibangun di atas tanah wakaf.

Persoalan wakaf dan perwakafan, dalam tradisi masyarakat mungkin tidak asing lagi terdengar di telinga. Sebab tradisi perwakafan ini sudah

Iqtishoduna: Jurnal Ekonomi dan Bisnis Islam, 3, No. 1, (2007): h. 12.

7 Ahmad Sirojudin Munir, "Optimalisasi Pemberdayaan Wakaf Secara Produktif," Ummul Qura 6, No. 2 (September 2018): h. 102. 
menggejala, atau bahkan melembaga sepanjang manusia ada (mesti dalam pengertian dan pengistilahan berbeda). Namun, pengaturan tentang sumber hukum, tata cara, prosedur dan praktik perwakafan dalam bentuk undang-undang bisa dibilang baru. Terlebih pengaturan ini diformulasikan dalam sebuah kajian komprehensif berbentuk buku, dari kasus perkasus, landasan-landasannya, hingga peraturan pemerintah yang berbentuk undang-undang. ${ }^{8}$

Selama ini praktik perwakafan tidak jarang dilakukan dengan caracara konvensional yang dalam praktiknya rentan bagi timbulnya persoalan, bahkan terkadang harus berakhir di pengadilan lantaran adanya perbedaan persepsi dan sengketa dalam perwakafan. Kondisi ini diperparah dengan maraknya indikasi yang mengarah pada praktik penyimpangan dalam pengelolaan benda-benda wakaf, dan tidak sedikit pula harta benda wakaf hilang bahkan menjadi hak milik seseorang yang dipercaya untuk mengelola.

Ironinya lagi wakaf oleh sebagian orang dianggap sebagai asset yang sangat menguntungkan untuk kepentingan pribadi atau bahkan dianggap asset yang bisa diperjual belikan yang manfaatnya hanya bisa dimanfaatkan oleh segelintir orang saja, kondisi terakhir ini jelas sangat bertentangan dengan tujuan dan fungsi wakaf yang diatur dalam Pasal 4 dan pasal 5 Undang-Undang Nomor 41 Tahun 2004 Tentang wakaf. Pertentangan ini akan berdampak buruk bagi tradisi wakaf juga akan menodai nilai-nilai luhur agama Islam yang mengkategorikan wakaf sebagai bentuk ketaaatan manusia kepada sang pencipta juga sebagai salah satu sarana untuk memajukan kesejahteraan umum.

Wakaf yang diajarkan oleh agama Islam selain mempunyai sandaran ideologi yang kuat dalam hal ketauhidan, yaitu segala sesuatu yang bertumpu pada keesaan Allah, juga mengajarkan manusia untuk mewujudkan keadilan sosial. Islam melarang dalam hal penguasaan harta kekayaan baik yang telah dimiliki secara perorangan maupun lembaga tanpa memperhatikan aspek sosial, karena pada dasarnya di dalam harta yang dimiliki terkandung hak orang lain juga, sehingga prinsip pemilikan

${ }^{8}$ Abdul Ghofur Anshori, Hukum dan Praktik Perwakafan di Indonesia, Cet. II, h. 1. 
harta dalam Islam menyatakan bahwa harta tidak dibenarkan hanya dikuasai oleh sekelompok orang, ini bisa dilihat dalam firman Allah pada Alquran Surat al-Taubah ayat 103 sebagai berikut:

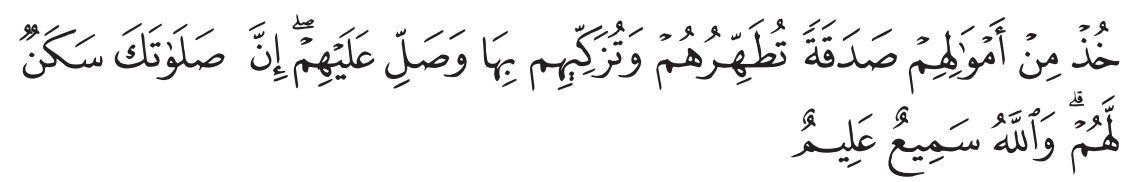

"Ambillah dari sebagian harta mereka sedekah (zakat), guna membersibkan dan mensucikan mereka dan mendo'alah untuk mereka.

Sesungguhnya doa kamu itu (menjadi) ketenteraman jiwa bagi mereka. dan Allah Maha mendengar lagi Maha mengetahui”. (Q.s. 9 [103]). ${ }^{9}$

Sebagai salah satu instrumen keagamaan bernilai ekonomis dan berdimensi sosial, perwakafan tanah merupakan konsekuensi logis dalam sistem pemilikan dalam Islam. Pemilikan harta benda dalam Islam harus disertai dengan pertanggungjawaban moral. Semua yang ada di langit dan di bumi ini adalah milik Allah. Pemilikan manusia atas harta benda merupakan amanah atau titipan belaka. Pengertian tersebut sesuai dengan ayat Alquran dalam surat al-Mâidah ayat 17 sebagai berikut:



Kepunyaan Allahlah kerajaan langit dan bumi dan apa yang ada diantara keduanya; Dia menciptakan apa yang dikehendaki-Nya. dan Allah Maha Kuasa atas segala sesuatu.

Praktik wakaf yang terjadi dalam kehidupan masyarakat sebelum berlakunya Undang-Undang Nomor 41 Tahun 2004 Tentang Wakaf masih bersifat konvensional atau lebih dikenal sistem kepercayaan, masyarakat hanya menyerahkan kepada tokoh masyarakat atau orang yang kredibel dan mampu untuk mengelola wakaf dengan sistem kepercayaan atau di bawah tangan. Faktor kepercayaan dan rasa ta'dzîm terhadap

9 Departemen Agama RI, Alquran dan Terjemahannya (Semarang: Yayasan Penyelenggara Penterjemah Alquran, Al Waah, 1995), h. 297. 
orang yang ditokohkan menjadi proses peralihan dari tanah yang tadinya berstatus Hak Milik menjadi Tanah Wakaf. Praktik semacam ini tentunya sangat rentan terhadap risiko yang akan dihadapi oleh masyarakat, karena faktor legalitas tanah wakaf hanya di bawah tangan dan hanya berdasarkan kepercayaan saja. Sehingga dalam berbagai kasus harta wakaf tidak terpelihara sebagaimana mestinya, beralih fungsi, terlantar atau beralih ketangan pihak ketiga dengan cara melawan hukum. Keadaan demikian sangatlah merugikan masyarakat, karena tanah wakaf tidak akan berjalan sebagaimana mestinya dan tidak bisa dilaksanakan sesuai dengan fungsinya.

Kabupaten Demak dikenal dengan sebutan Kota Wali memiliki masyarakat yang mayoritas memeluk agama Islam. Dalam segala urusan baik dalam hal ubûdiyah maupun muamalah, masyarakat sangat berpegang teguh pada syari'at Islam. Bagi mereka hukum Islam merupakan pondasi atau dasar bagi setiap pola perilakunya. Begitu juga dalam hal perwakafan. Mayoritas hanya berpedoman rasa kepercayaan dan lillahi ta'ala dengan harapan mendapat berkah dan rida dari Allah Swt. Sehingga tidak sedikit dari mereka yang mewakafkan tanahnya dengan cara lisan tanpa memperdulikan pentingnya legalitas tanah wakaf itu sendiri. Imbasnya memunculkan beberapa permasalahan dalam perwakafan.

Ada dampak positif dan negatif yang timbul sebagai akibat daripada wakaf sebagai ibadah lillahi táala. Dampak positifnya adalah perbuatan tersebut murni dilandasi oleh rasa iman dan ikhlas sematamata pengabdian kepada Allah Swt. Dampak negatifnya adalah kegiatan wakaf tersebut dianggap sebagai kejadian yang tidak perlu diketahui apalagi diumumkan kepada orang lain. Akibatnya, wakaf semakin sulit untuk diidentifikasi secara pasti. ${ }^{10}$ Kondisi yang demikian ini tentunya menjadikan masalah dalam hal status tanah wakaf itu sendiri. Hal ini karena banyaknya tanah wakaf yang sulit teridentifikasi oleh pemerintah.

Harta wakaf pada prinsipnya adalah milik umat dan manfaatnya

${ }^{10}$ Abdul Ghofur Anshori, Hukum dan Praktik Perwakafan di Indonesia, h.1. 
akan dikembalikan kepada umat. Idealnya, keberadaan, pengelolaan, dan pengembangan harta wakaf adalah tanggungjawab kolektif seluruh masyarakat. Keberhasilan pengelolaan wakaf tidak semata-mata ditentukan oleh banyaknya wakaf yang dikelola, melainkan sejauh mana pengelolaan dan pemberdayaan wakaf akan memberikan nilai tambah bagi pengembangan kegiatan produktif maupun untuk mengatasi masalahmasalah sosial yang bersumber dari kesenjangan ekonomi. ${ }^{11}$

Dengan demikian, keberadaan lembaga yang mengurusi harta wakaf mutlak diperlukan sebagaimana yang telah dilakukan oleh sebagian negara-negara Islam seperti di negara Arab Saudi. Di negara ini wakaf ada beberapa macam, ada yang berbentuk bangunan fisik yang peruntukannya untuk tempat ibadah, selain tersebut ada juga wakaf yang peruntukannya untuk pemeliharaan dan pembangunan Masjidil Haram di kota Makah dan masjid Nabawi di Madinah, seperti bangunan untuk penginapan jamah haji berupa bangunan seperti hotel, dan ada juga yang peruntukannya untuk kesejahteraan masyarakat seperti pembangunan rumah untuk penduduk. Di Indonesia, masalah pengurusan dan pengelolaan wakaf masih terkesan lamban, sekalipun mayoritas penduduknya beragama Islam dan menempati rangking pertama dari populasi umat Islam dunia. Implikasi dari kelambanan ini menyebabkan banyaknya harta-harta wakaf yang kurang terurus dan bahkan masih ada yang belum dimanfaatkan. ${ }^{12}$ Di sinilah peran semua elemen baik masyarakat maupun pemerintah agar wakaf bisa berkembang.

Mendasarkan pertimbangan tersebut di atas, pemerintah telah menerbitkan Undang-Undang Nomor 41 Tahun 2004 Tentang Wakaf. Lahirnya Undang-Undang Nomor 41 Tahun 2004 tentang Wakaf tersebut, memberikan setitik harapan bagi perkembangan dinamis wakaf di Indonesia. Pasalnya, undang-undang tersebut mengamanatkan pemerintah untuk memberikan pembinaan terhadap lembaga wakaf

${ }^{11}$ Muhammad Alfin Syauqi, "Optimalisasi Pengelolaan Wakaf Uang Untuk Kesejahteraan Umum,” Jurnal Kanun Ilmu Hukum 63, No. 16 (Agustus 2014): h. 372.

12 Junaidi Abdullah Nur Qodin, "Penyelesaian Sengketa Wakaf dalam Hukum Positif," Jurnal Ziswaf 1, No. 1 (Juni 2014): h. 39. 
di Indonesia agar dapat berperan dalam mengembangkan harta wakaf.

Berdasarkan hal di atas, permasalahan yang muncul adalah bagaimanakah kedududukan hukum tanah wakaf sebelum berlakunya UndangUndang Nomor 41 Tahun 2004 Tentang Wakaf di Kabupaten Demak dan masalah-masalah apa yang timbul? Bagaimanakah pelaksanaan pengesahan tanah wakaf sesudah berlakunya Undang-Undang Nomor 41 Tahun 2004 Tentang Wakaf di Kabupaten Demak dan kendala-kendala apa yang dihadapi? Bagaimana optimalisasi pengelolaan dan fungsi sosial wakaf dan Implikasinya terhadap peningkatan taraf hidup masyarakat di Kabupaten Demak?

\section{Kedududukan Hukum Tanah Wakaf Sebelum Berlakunya Undang- Undang Nomor 41 Tahun 2004 Tentang Wakaf dan Masalah-Masalah Yang Timbul.}

Wakaf adalah salah satu bentuk ibadah melalui pengorbanan harta benda yang manusia miliki untuk kepentingan umum, kemanusiaan, dan keagamaan. Karena sifatnya kemanusiaan maka sudah sepatutnya dalam pelaksanaannya sesuai dengan peraturan yang telah ditetapkan sehingga dalam implementasinya tepat sasaran.

Namun sebelum berlakunya Undang-Undang Nomor 41 Tahun 2004 Tentang Wakaf, pelaksanaan wakaf di Kabupaten Demak masih bersifat konvensional artinya masih bersifat saling percaya (di bawah tangan). Mayoritas masyarakat yang mewakafkan tanahnya (wakif) masih menempuh cara-cara tradisional yaitu hanya dengan mempercayakan kepada tokoh agama atau tokoh masyarakat yang dipercaya, dituakan dan dianggap mampu untuk menjalankan amanat wakif untuk mengurusi dan mengelola tanah wakafnya. Bagi masyarakat mendapat keberkahan dan keridaan dari Allah adalah tujuan yang paling asasi dari sebuah sedekah jariyah. Ikhlas dan tanpa pamrih itulah yang menjadi dasar bagi mereka mempercayakan begitu saja tanahnya kepada seseorang yang dianggap kredibel dan mampu tanpa berpikir akibat yang akan terjadi. Keadaan semacam ini tentunya riskan, akan timbulnya permasalahan-permasalahan di kemudian hari. Hal ini disebabkan tidak adanya faktor legalitas yang menjamin keamanan bagi tanah wakaf itu sendiri. 
Tujuan utama diadakan legalisasi tanah wakaf yaitu untuk menjamin kepastian hukum atas tanah wakaf itu sendiri dan menghindari permasalahan-permasalahan yang timbul dikemudian hari, namun dalam kenyataan yang terjadi, kedudukan tanah wakaf sebelum berlakunya Undang-Undang Nomor 41 Tahun 2004 Tentang Wakaf menimbulkan permasalahan-permasalahan, yaitu:

a. Tanah tidak jelas kepemilikannya;

Mengenai problematika wakaf dalam hal tanah tidak jelas kepemilikannya biasanya terjadi ketika wakif meninggal dunia dan ahli waris banyak sedangkan wakaf hanya diikrarkan secara lisan. Maka seharusnya dari ahli waris menunjuk salah satu ahli waris untuk mencantumkan namanya disertifikat hak milik tersebut. Tetapi permasalahannya kadang tidak semudah yang diharapkan. Karena bisa saja ahli waris berebut untuk mencantumkan namanya disertifikat tersebut. Dalam hal ini maka KUA setempat menyerahkan kepada ahli waris untuk menentukannya dengan dimediasi Kepala Desa dan tokoh masyarakat setempat. Proses mediasi tersebut bertujuan agar ahli waris sepakat untuk mencantumkan salah satu nama ahli waris disertifikat tanahnya sehingga kepemilikan atas tanah semakin jelas dan mempermudah proses dalam legislasi tanah wakaf.

b. Tanah wakaf diminta kembali oleh ahli waris wakif;

Pada permasalahan dimintanya kembali tanah wakaf oleh ahli waris wakif, hal ini memang sering terjadi dalam praktik perwakafan. Banyak dijumpai harta wakaf ditarik kembali oleh ahli waris wakif setelah wakif meninggal dunia. Faktor yang menyebabkan permasalahan ini terjadi karena kesalahpahaman ahli waris tentang wakaf, mereka beranggapan bahwa wakaf akan berakhir waktunya ketika orang yang mewakafkan meninggal dunia. Hal yang sebenarnya wakaf adalah bersifat abadi, meskipun ada sebagian pendapat ulama' yang mengatakan bahwa wakaf bisa dengan jangka waktu tertentu, tetapi yang lebih afsah bahwa wakaf itu bersifat abadi. Selain itu proses perwakafan yang hanya dengan lisan bisa berimplikasi ditariknya kembali tanah wakaf ahli waris. 
Jika hal ini terjadi maka musyawarah yang menjadi dasar utama untuk mengembalikan harta wakaf tersebut. Dalam musyawarah pihak-pihak yang terlibat bisaanya Kepala Desa/Kelurahan, Nazhir, Ketua RT dan RW, tokoh masyarakat dan juga melibatkan warga. Penyelesaian melalui jalur pengadilan jarang menjadi pilihan, karena bukti-buktinya pun kurang cukup untuk mengembalikan harta wakaf ke posisi semula.

c. Tanah dikuasai secara turun temurun oleh nazhir.

Permasalahan selanjutnya adalah dikuasainya tanah wakaf secara turun temurun oleh nazhir. Kondisi ini tentunya akan terjadi kerancuan dalam pengelolaan dan pengembangan wakaf dan tentunya proses pelestarian harta wakaf pun tidak tepat sasaran. Karena hasilnya digunakan untuk kepentingan pribadi bukan umat. Faktor yang menyebabkan adalah ahli waris, nazhir menganggap bahwa tanah wakaf tersebut adalah tanah waris yang bisa dirasakan turun temurun oleh keluarga nazhir. Sehingga pengeloaan tanah wakaf tersebut diperlakukan sebagai tanah pribadi atau tanah hak milik. Faktor lain yang menyebabkan masalah ini kurangnya pahamnya nazhir akan tujuan wakaf yang sebenarnya, di samping tidak adanya legalitas wakaf yang menyebabkan harta wakaf tersebut dikuasai secara temurun oleh ahli waris nazhir setelah nazhir meninggal dunia.

Sehingga dapat disimpulkan kedudukan hukum tanah wakaf sebelum berlakunya Undang-Undang Nomor 41 Tahun 2004 Tentang Wakaf tidak kuat, karena faktor legalitas ikrar masih bersifat lisan (di bawah tangan), tentunya riskan terhadap timbulnya permasalahanpermasahan, sudah dipastikan dapat menghambat dalam pengelolaan dan pengembangan tanah wakaf itu sendiri.

\section{Pelaksanaan Pengesahan Tanah Wakaf Sebelum dan Sesudah Berlakunya Undang-Undang Nomor 41 Tahun 2004 Tentang Wakaf Serta Kendala-Kendala Dihadapi.}

Wakaf merupakan sedekah jariyah yang hukumnya sunah, karena wakaf merupakan salah satu tuntunan agama Islam yang mempunyai dimensi ketauhidan yaitu segala sesuatu yang mengharap rida Allah. 
Wakaf juga merupakan ibadah ijtimâizyah (ibadah sosial) yaitu sebagai salah satu penunjang perekonomian umat Islam.

Wakaf di Indonesia telah dikenal dan dilaksanakan sejak awal masuknya Islam di Indonesia, namun pelaksanaannya masih bersifat tradisional dan disesuaikan dengan adat yang ada di masyarakat. Ketika itu belum ada aturan khusus yang bersifat formal yang mengatur mengenai pelaksanaan wakaf. Namun Pada masa penjajahan, pemerintah Kolonial Belanda berupaya memberlakukan pengaturan administrasi terhadap pelaksanaan wakaf, misalnya pendataan harta benda wakaf serta ketentuan izin dalam pelaksanaan wakaf, namun mendapatkan resistensi dari masyarakat muslim, karena menilai pihak Belanda tidak boleh melakukan intervensi terhadap pelaksanaan ajaran Islam. ${ }^{13}$

Dengan demikian wakaf dalam pelaksanaannya mempunyai dua aspek, yaitu aspek agamis dan administratif. Sebagai suatu lembaga kebajikan dan sosial dalam Islam sudah sepatutnya pelaksanaan perwakafan tanah dilakukan dengan mengikuti ketentuan agama, namun untuk menjaga keabsahannya dan guna menjaga kelestariannya seharusnya pelaksanaan perwakafan tanah juga harus mengikuti langkah administratif, yaitu mengikuti semua tata cara yang telah dipersyaratkan oleh pemerintah yang terwujud dalam peraturan perundang-undangan yang mengatur tentang wakaf.

Berbeda halnya yang terjadi di masyarakat Kabupaten Demak yang terkenal masih kental nuansa religiusnya. Dalam pola kehidupan sehari-hari baik dalam hal beribadah maupun bermuamalah, mereka sangat berpegang teguh pada syari'at Islam. Begitu juga dalam hal perwakafan, mayoritas dari mereka dalam hal mewakafkan tanahnya sangat berpedoman pada syari'at agama. Bagi mereka, amal kebajikan tidak perlu diperlihatkan atau diketahui oleh orang, tujuannya hanya untuk memperoleh rida Allah. Mereka berpedoman pada sebuah hadis yang berbunyi "Jika tangan kanan beramal maka tangan kiri hendaknya tidak mengetahuinya“. Prinsip itulah yang menjadikan mereka lebih

${ }^{13}$ Asni, "Pengembangan Hukum Perwakafan di Indonesia," Jurnal Al-'Adl 7, no. 2 (Juli 2014): h. 5. 
mempercayakan dalam hal urusan perwakafan kepada seorang kyai atau tokoh masyarakat yang dianggap mampu meskipun tidak diketahui kualitasnya. Pada akhirnya, banyak sekali tanah wakaf yang tidak terkelola secara maksimal.

Semestinya masyarakat Demak sadar akan pentingnya proses legalitas tanah wakaf, bukan berarti keikhlasan itu dengan tidak mengikuti peraturan yang telah ditetapkan. Karena dalam pelaksanaan ibadah seharihari, Allah telah mengatur tata caranya, baik dalam bentuk ibadah khusus (hablum minallâh) yang ditentukan cara, waktu, dan tempatnya seperti salat, puasa, dan haji, maupun dalam bentuk ibadah umum (hablum minannâs) atau muamalah. Manifestasi pelaksanaan ibadah dipraktikkan melalui pengabdian keseluruhan diri manusia beserta segala sesuatu yang dimilikinya, baik melalui pengabdian badan seperti salat, zakat atau juga melalui pengabdian yang berupa pengorbanan harta benda yang dimiliki diperuntukkan untuk kepentingan manusia atau kepentingan umum seperti zakat, sedekah, infak dan wakaf. Wakaf adalah salah satu bentuk ibadah melalui pengorbanan harta benda yang manusia miliki untuk kepentingan umum, kemanusian, dan keagamaan. Karena sifatnya kemanusiaan, sudah sepatutnya maka dalam pelaksanaannya harus sesuai dengan peraturan yang telah ditetapkan sehingga dalam implementasinya tepat sasaran.

Menurut Ahmad Anas selaku Kepala Kantor Urusan Agama Kecamatan Demak keengganan masyarakat untuk mendaftarkan tanah wakafnya karena masih mempunyai rasa aman dan pemahaman yang salah terhadap wakaf. Mereka beranggapan dengan mendaftarkan tanah maka mereka sama sekali tidak mempunyai bagian dari wakaf. Artinya, dengan mendaftarkan tanahnya, mereka tidak mempunyai hak sama sekali dalam mengelola dan mengembangkan wakaf tersebut. ${ }^{14}$

Adapun menurut Sholikhul Hadi, selaku kepala Kantor Urusan agama (KUA) Kecamatan Bonang, mengenai tanah wakaf yang tidak didaftarkan di Kantor Badan Pertanahan Nasional, dikarenakan ke-

${ }^{14}$ Wawancara dengan Ahmad Anas, Kepala Kantor Urusan Agama Kecamatan Demak, 27 Mei 2016. 
tidaktahuan masyarakat akan pentingnya legalitas tanah wakaf, serta kebanyakan Nazhir kurang memahami tentang tatacara perwakafan. Mereka berpendapat wakaf adalah amal ibadah yang tidak perlu untuk ditonjol-tonjolkan sehingga tidak perlu didaftarkan, selain itu, prosedur pendaftaran tanah yang memakan biaya dan waktu berimplikasi terhadap keengganan pengelola wakaf untuk mendaftarkan tanahnya. ${ }^{15}$ Selain itu juga karena masih adanya wakif yang berkeyakinan bahwa penyerahan tanah wakaf cukup dilakukan secara lisan dan merasa bukan kewajibannya lagi mengurus administrasinya, karena tanah tersebut menurut pendapatnya, telah menjadi milik masyarakat atau agama. ${ }^{16}$

Ketidakpahaman masyarakat akan pentingnya sertifikat tanah wakaf dan akibat yang timbul nantinya juga tidak mudahnya ditemukan figur yang benar-benar tahu peraturan wakaf, menjadikan masyarakat enggan untuk mendaftarkan tanahnya. Selain itu, tingginya biaya yang dikeluarkan baik dalam bentuk biaya untuk pensertifikatan maupun biaya lain yang timbul akibat proses pensertifikatan tanah menjadikan mereka memilih wakaf dengan lisan saja. Mereka beranggapan wakaf merupakan ibadah yang tidak perlu dipamerkan kepada siapapun, karena menurut mereka wakaf hanya mengharap rida Allah semata. ${ }^{17}$ Padahal karena tidak adanya kepastian hukum mengenai status sebidang tanah khusus tanah wakaf tersebut, senantiasa akan mengundang timbulnya berbagai sengketa, tidak jarang melibatkan sekelompok orang, sehingga dengan demikian kehidupan masyarakat akan terganggu. ${ }^{18}$

Sejatinya masyarakat tidak perlu takut dan enggan untuk mendaftarkan tanahnya. Menurut Lasdi, Kepala Bagian Pendaftaran dan Informasi Kantor Badan Pertanahan Nasional Kabupaten Demak, biaya

${ }^{15}$ Wawancara dengan Sholikhul Hadi, Kepala Kantor Urusan Agama Kecamatan Bonang, 17 Juni 2016.

${ }^{16}$ Fetrimen, "Pemberdayaan Asset Tanah Wakaf dan Non Wakaf Sebagai Sarana Pendidikan di Pimpinan Wilayah Muhammadityah Jambi," Jurnal Ekonomi Islam 7, no. 2 (September 2016): h. 58.

${ }^{17}$ Wawancara dengan Masrohan, Kepala Kantor Urusan Agama Kecamatan Kebonagung, 29 Juni 2016.

${ }^{18}$ Ike Natalia Dahliana, "Tinjauan Yuridis Terhadap Legalitas Tanah Wakaf yang Belum Disertifikatkan di Kota Samarinda," Jurnal Prediksi Vol 7, No. 8 (Februari 2009): h. 48-49. 
yang dikeluarkan untuk pensertifikatan tanah adalah tidak semahal sebagaimana yang dipikirkan oleh masyarakat. Sebenarnya alasan yang mendasar ialah lamanya proses pendaftaran dan besarnya biaya transportasi yang dikeluarkan dalam proses pengurusan pendaftaran tanah sehingga masyarakat enggan melakukannya. Jika dilihat risiko yang timbul akibat tidak didaftarkannya tanah tidak sebanding dengan biaya yang dikeluarkan. Karena faktor legalitas harus diutamakan untuk keamanan status tanah di masa mendatang. ${ }^{19}$

Berdasarkan data yang didapat dari Kantor Badan Pertanahan Nasional Kabupaten Demak, ${ }^{20}$ mengenai pendaftaran tanah dapat diklasifikasikan sebagai berikut: semisal tanah berukuran 100 M2

1. Untuk tanah yang sudah bersertifikat

a. Seluruhnya

\begin{tabular}{llc}
\hline 1 & Penghapusan & Rp. 25.000 \\
\hline 2 & Kutipan & Rp. 25.000 \\
\hline 3 & Pendaftaran & Rp. 25.000 \\
\hline & Jumlah & Rp. 75.000 \\
\hline b. & Sebagian & \\
\hline 1 & Penghapusan & Rp. 25.000 \\
\hline 2 & Pendaftaran & Rp. 25.000 \\
\hline 3 & Transport Ukur & Rp. 25.000 \\
\hline 4 & Biaya Ukur & Rp. 68.900 \\
\hline & Jumlah & Rp. 143.900
\end{tabular}

${ }_{19}$ Wawancara dengan Lasdi, Kepala Bagian Pendaftaran dan Informasi Badan Pertanahan Nasional Kabupaten Demak, 1 Juli 2016.

${ }^{20}$ Data Kantor Badan Pertanahan Nasional Kabupaten Demak tahun 2016. 
2. Untuk tanah yang belum terdaftar

a. Perkotaan

\begin{tabular}{clc}
\hline 1 & Pendaftaran & Rp. 25.000 \\
\hline 2 & Panitia A & Rp. 322.000 \\
\hline 3 & Transport Panitia A & Rp. 180.000 \\
\hline 4 & Biaya Ukur & Rp. 68.900 \\
\hline 5 & Transport Ukur & Rp. 45.000 \\
\hline Jumlah & & Rp. 640.900 \\
\hline
\end{tabular}

b. Pedesaan

\begin{tabular}{rlr}
\hline 1 & Pendaftaran & Rp. 25.000 \\
\hline 2 & Panitia A & Rp. 161.000 \\
\hline 3 & Transport Panitia A & Rp. 180.000 \\
\hline 4 & Transport Ukur & Rp. 45.000 \\
\hline 5 & Biaya Ukur & Rp. 68.900 \\
\hline & Jumlah & Rp. 479.900 \\
\hline
\end{tabular}

Tabel di atas menunjukkan sebenarnya biaya pengurusan sertifikasi tanah tidak semahal sebagaimana yang dibayangkan masyarakat. Jika dibanding faktor keamanan dan legalitas tanah, biaya tersebut relatif murah, apalagi jika dibandingkan dengan naiknya nilai jual tanah tersebut jelas sangat tidak memberatkan bagi masyarakat itu sendiri.

Mengenai Proses perwakafan tanah di kabupaten Demak sebagaimana dilaksanakan Kantor Urusan Agama (KUA) Kecamatan, yaitu sebagai berikut. ${ }^{21}$ Apabila seseorang tergerak hatinya untuk beramal kebajikan dengan berwakaf maka calon wakif harus datang ke Kantor Urusan

${ }^{21}$ Ahmad Anas, Kepala Kantor Urusan Agama Kecamatan Demak, wawancara. 
Agama untuk bertanya tentang tata cara mewakafkan tanah milik, kemudian calon wakif akan mendapatkan penjelasan dari kepala Kantor Urusan Agama tentang prosedur perwakafan tanah hak milik. Setelah mendapatkan penjelasan selanjutnya calon wakif harus melengkapi syaratsyarat yang diperlukan. Adapun syarat-syarat yang harus dipenuhi adalah pertama, Sertifikat Hak Milik atas tanah atau bukti surat kepemilikan tanah dari yang wakif. Kedua, surat keterangan dari Lurah atau Kepala Desa setempat yang menyatakan bahwa tanah tersebut benar-benar milik wakif dan tidak dalam sengketa. Ketiga, Surat Keterangan Pendaftaran Tanah (SKPT) dari kantor pertanahan Kabupaten atau Kotamadya. Keempat, meneliti dua orang yang akan menjadi saksi pada saat ikrar wakaf. Kelima, meneliti nazhir baik perorangan maupun badan hukum yang ditunjuk dan diserahi pengurusan tanah wakaf setelah syarat-syarat yang diperlukan dianggap sudah lengkap maka calon wakif datang ke Kantor Urusan Agama untuk menyerahkan persyaratan tersebut kepada kepala Kantor Urusan Agama.

Kepala Kantor Urusan Agama setelah menerima berkas persyaratan tersebut kemudian meneliti kelengkapan berkas tersebut. Setelah persyaratan dianggap lengkap maka Kepala Kantor Urusan Agama kemudian pertama meneliti kehendak wakif, kedua meneliti tanah yang hendak diwakafkan, ketiga meneliti para saksi ikrar wakaf, keempat meneliti calon nazhir dan mengesahkannya, kelima meneliti surat-surat kelengkapan yang diperlukan untuk wakaf, keenam calon wakif melaksanakan ikrar wakaf dengan lisan yang jelas dan tegas kepada nazhir yang telah ditunjuk di depan PPAIW dan para saksi dan dituangkan dalam model W1 yaitu ikrar wakaf dan W2 yaitu akta ikrar wakaf. W1 dan W2 masing-masing dibuat rangkap tiga. W1 diberikan kepada Nazhir, PPAIW dan Wakif sedangkan W2 lembar satu untuk disimpan, lembar kedua untuk keperluan pendaftaran dipertanahan dan lembar ketiga untuk Pengadilan Agama setempat. Setelah ikrar terlaksana Kepala KUA memerintahkan nazhir untuk mengurus ke kantor pertanahan (BPN) dan terbitlah sertifikat tanah wakaf, tapi apabila persyaratan belum terpenuhi maka Kepala Kantor Urusan Agama memerintahkan calon wakif untuk melengkapinya terlebih dahulu. 
Selanjutnya ditegaskan oleh Nur Ali Kepala Penyelenggara Zakat dan Wakaf Kantor Urusan Agama Kecamatan Kebonagung 22 bahwa mekanisme legalisasi tanah wakaf ada dua macam, yakni proses perwakafan tanah baru dan proses perwakafan tanah lama. Proses perwakafan baru adalah proses perwakafan tanah yang dilakukan setelah adanya peraturan yang mengatur tentang wakaf. Wakif datang ke Kantor Urusan Agama Kecamatan yaitu kepada Pejabat Pembuat Akta Ikrar Wakaf dan menyampaikan kehendaknya untuk mewakafkan tanah miliknya. Tindakan selanjutnya ialah Kepala Kantor Urusan Agama Kecamatan mendaftarkan ikrar wakaf itu ke kantor Badan Pertanahan Nasional (BPN) Kabupaten sebagai instansi yang berwenang menyelenggarakan pendaftaran tanah. Untuk pendaftaran tanah di kantor Badan Pertanahan Nasional selain ikrar wakaf dan surat pengesahan nazhir juga disertakan surat-surat tanahnya. Apabila tanah tersebut sudah ada sertifikatnya, maka prosesnya mudah. Pejabat pertanahan nasional cukup mengadakan pencocokan dan perobahan dari nama pemilik menjadi wakif serta membubuhkan nama nazhirnya, baik pada sertifikat maupun pada buku tanahnya. Apabila ternyata tanah yang telah diwakafkan tersebut belum bersertifikat, maka prosesnya agak memakan waktu dan biaya untuk memperoleh sertifikat sesuai dengan ketentuan Peraturan Pemerintah Nomor 24 Tahun 1997 Tentang Pendaftaran Tanah. ${ }^{23}$ Proses pengurusan sertifikat dapat dilakukan bersama dengan pengajuan pendaftaran tanah wakaf ke Kantor Badan Pertanahan Kabupaten Demak. Pengajuan oleh Kantor Urusan Agama Kecamatan atas nama nazhir dan nazhirlah yang menyelesaikan proses selanjutnya.

Selanjutnya mengenai proses atau tata cara wakaf lama yaitu wakaf tanah yang sudah terjadi sebelum berlakunya peraturan perundangan yang mengatur tentang wakaf, atau bisa dikatakan jauh sebelum peraturan perundangan tentang wakaf. Terdapat proses ikrarnya terjadi di hadapan wakif secara lisan dan tidak tertulis karena semata-mata hanya mengharapkan rida Allah. Maka proses pendaftarannya di Kantor

${ }^{22}$ Wawancara dengan Nur Ali, Kepala Penyelenggara Zakat dan Wakaf Kantor Urusan Agama Kecamatan Kebonagung, 30 Juni 2016.

${ }^{23}$ Lihat selengkapnya dalam Peraturan Pemerintah Nornor 24 Tahun 1997 Tentang Pendaftaran Tanah dan Peraturan Menteri Agraria No 3 Tahun 1997 Tentang Peraturan Pelaksanaan Peraturan Pemerintah Nornor 24 Tahun 1997 Tentang Pendaftaran Tanah. 
Urusan Agama sedikit berbeda. Jika wakaf baru dengan dibuatkan akta ikrar wakaf. Wakaf lama dibuat surat laporan dari nazhir lama yang diperkuat surat kesaksian Kepala Desa setempat. Kemudian Pejabat Pembuat Akta Ikrar Wakaf (PPAIW) menerbitkan Akta Pengganti Akta Ikrar Wakaf (APAIW). Proses selanjutnya ke kantor Badan Pertanahan Nasional sebagaimana yang dilakukan pada pendaftaran tanah wakaf baru.

Berdasarkan pada proses perwakafan tanah yang terjadi di Kabupaten Demak tersebut berikut ini diperbandingkan dengan ketentuan tata cara wakaf menurut Kompilasi Hukum Islam adalah sebagaimana diatur dalam Pasal 223, yaitu sebagai berikut:

1. Pihak yang hendak mewakafkan dapat menyatakan ikrar wakaf dihadapan Pejabat Pembuat akta Ikrar Wakaf untuk melaksanakan ikrar wakaf.

2. Isi dan bentuk Ikrar wakaf ditetapkan oleh Menteri Agama.

3. Pelaksanaan Ikrar Wakaf demikian pula pembuatan Ikrar Wakaf, dianggap sah jika dihadiri dan disaksikan oleh sekurang-kurangnya 2 (dua) orang saksi.

4. Dalam melaksanakan Ikrar Wakaf seperti dimaksud ayat (1) pihak yang mewakafkan diharuskan menyerahkan kepada Pejabat yang tersebut dalam Pasal 215 ayat (6), surat-surat sebagai berikut:

a. Tanda bukti pemilikan harta benda;

b. Jika benda yang diwakafkan berupa benda tidak bergerak, maka harus disertai surat keterangan oleh Kepala Desa, yang diperkuat oleh Camat setempat yang menerangkan pemilikan benda tidak bergerak dimaksud;

c. Surat atau dokumen tertulis yang merupakan kelengkapan dari benda yang bersangkutan.

Adapun mengenai tata cara ikrar wakaf sebagaimana diatur dalam Undang-undang Republik Indonesia No. 41 Tahun 2004 Tentang Wakaf yaitu: ${ }^{24}$

${ }^{24}$ Lihat selengkapnya Undang-Undang Nomor 41 Tahun 2004 Tentang Wakaf dan Peraturan Pemerintah Nomor 42 Tahun 2006 Tentang Peraturan Pelaksanaan Undang-Undang Nomor 41 Tahun 2004 Tentang Wakaf. 
Pasal 17;

1. Ikrar wakaf dilaksanakan oleh Wakif kepada Nazhir dihadapan PPAIW dengan disaksikan oleh 2 (dua) orang saksi.

2. Ikrar wakaf sebagaimana dimaksud pada ayat (1) dinyatakan secara lisan dan/atau tulisan serta dituangkan dalam akta ikrar wakaf oleh PPAIW.

Pasal 18;

"Dalam hal wakif tidak dapat menyatakan ikrar wakaf secara lisan atau tidak dapat hadir dalam pelaksanaan ikrar wakaf karena alasan yang dibenarkan oleh hukum, wakif dapat menunjuk kuasanya dengan surat kuasa yang diperkuat oleh 2 (dua) orang saksi.

Langkah berikutnya dijelaskan dalam Pasal 224 Kompilasi Hukum Islam, yaitu:

"Setelah Akta Ikrar dilaksanakan sesuai dengan ketentuan dalam pasal 223 ayat (3) dan (4), maka Kepala Kantor Urusan Agama Kecamatan atas nama nadzir yang bersangkutan diharuskan mengajukan permohonan kepada Camat untuk mendaftarkan perwakafan benda yang bersangkutan guna menjaga keutuhan dan kelestarian.

Setelah ikrar wakaf dilaksanakan maka proses selanjutnya adalah Pejabat Pembuat Akta Ikrar Wakaf (PPAIW) bertindak atas nama nazhir paling lambat tujuh hari semenjak penandatanganan akta ikrar wakaf harus sudah mendaftarkan tanah wakaf kepada Instansi yang berwenang yaitu Kantor Badan Pertanahan Nasional dengan menyertakan (1) salinan akta ikrar wakaf, (2) surat-surat atau dokumen lain yang terkait dengan tanah wakaf, setelah persyaratan lengkap diterima oleh Kantor Badan Pertanahan Nasional langkah selanjutnya instansi yang berwenang menerbitkan bukti pendaftaran tanah wakaf tersebut. Kemudian bukti yang pendaftaran yang diterbitkan oleh instansi berwenang tersebut diserahkan PPAIW kepada nazhir sebagai bukti bahwa proses pendaftaran telah terjadi.

Proses pendaftaran tanah sebagaimana yang diatur dalam Peraturan Pemerintah Republik Indonesia Nomor 24 Tahun 1997 Tentang Pendaftaran Tanah dalam Pasal (5) dan (6) adalah sebagai berikut: ${ }^{25}$

${ }^{25}$ Lihat selengkapnya dalam Peraturan Pemerintah Nornor 24 Tahun 1997 Tentang 
Pasal 5 menyatakan:

"Pendaftaran tanah diselenggarakan oleh Badan Pertanahan Nasional".

Pasal 6 menyatakan:

1. Dalam rangka penyelenggaraan pendaftaran tanah sebagaimana dimaksud dalam Pasal 5 tugas pelaksanaan pendaftaran tanah dilakukan oleh Kepala Kantor Pertanahan, kecuali kegiatan-kegiatan tertentu yang oleh Peraturan Pemerintah ini atau perundang-undangan yang bersangkutan kepada Pejabat lain.

2. Dalam melaksanakan pendaftaran tanah, Kepala Kantor Pertanahan dibantu oleh PPAT dan Pejabat lain yang ditugaskan untuk melaksanakan kegiatan-kegiatan tertentu menurut Peraturan Pemerintah ini dan peraturan perundang-undangan yang bersangkutan

Dengan demikian dapat disimpulkan bahwa proses perwakafan tanah yang terlaksana di Kabupaten Demak telah sesuai dengan Undang-undang No. 41 Tahun 2004 Tentang wakaf Pasal (17) dan (18) dan Peraturan Pemerintah No. 24 Tahun 1997 Tentang Peraturan Pelaksanaan Undangundang No. 41 Tahun 2004 Tentang Wakaf Pasal (5) dan (6) juga Pasal 223 Kompilasi Hukum Islam.

Setelah proses perwakafan tanah menurut Undang-Undang Nomor 41 Tahun 2004 Tentang Wakaf selesai, maka langkah selanjutnya adalah melaksanakan fungsi wakaf, namun dalam pelaksanaannya ada beberapa masalah yang timbul, yaitu:

1. Minimnya jumlah nazhir di setiap desa;

Mengenai permasalahan minimnya jumlah nazhir disetiap desa, ada keuntungan dan kerugiannya. Keuntungannya akan lebih mudah melakukan pengawasan terhadap nazhir tersebut. Sedangkan kerugiannya nazhir tidak bisa maksimal dalam pengawasan tanah wakaf sehingga banyak sekali tanah wakaf yang tidak terurus. Terkait kasus ini, pihak Kantor Urusan Agama akan melakukan musyawarah dengan kepala desa setempat untuk mengangkat

Pendaftaran Tanah, Peraturan Menteri Agraria No 3 Tahun 1997 Tentang Peraturan Pelaksanaan Peraturan Pemerintah Nornor 24 Tahun 1997 Tentang Pendaftaran Tanah, dan Peraturan Pemerintah No 46 Tahun 2002 Tentang Biaya Pengurusan Pelayanan Pertanahan. 
nazhir baru di daerah yang minim jumlah nazhirnya sehingga pengelolaan tanah wakaf oleh nazhir dapat berjalan efektif dan maksimal.

2. Nazhir kurang professional;

Pengelolaan harta wakaf produktif, pihak yang paling berperan berhasil tidaknya dalam pemanfaatan dan pengelolaan harta wakaf adalah nazhir wakaf, yaitu seorang atau sekelompok orang dan badan hukum yang diserahi tugas oleh wakif (orang yang mewakafkan harta) untuk mengelola harta wakaf. Walaupun dalam kitab-kitab fikih ulama tidak mencantumkan nazhir wakaf sebagai salah satu rukun wakaf, karena wakaf merupakan ibadah tabarru' (pemberian yang bersifat sunnah). Namun peran nazhir sangatlah dibutuhkan dalam pengelolaan harta wakaf. Apalagi jika memperhatikan tujuan wakaf yang ingin melestarikan hasil dari harta wakaf yang ditujukan untuk kepentingan umat, maka keberadaan nazhir yang profesional sangatlah dibutuhkan. Karena harta wakaf bukan hanya sekedar dikelola saja namun bagaimana dikelola dan dikembangkan sehingga menjadi harta yang produktif yang menjadi sangat berarti bagi umat atau masyarakat.

Nazhir menempati pos yang sentral dan penting dalam pengelolaan harta wakaf, karena sebagai leader dan juga manajer. Sebagai leader, tugasnya adalah sebagai pemimpin dalam proses pengelolaan wakaf. Sedang sebagai manajer, nazhir harus mampu menyusun program dan rencana ke depan untuk pengembangan wakaf. Selain berkewajiban menjaga, nazhir juga berkewajiban mengembangkan dan melestarikan manfaat dari harta yang diwakafkan sehingga pemanfaatan bisa tepat sasaran.

3. Peruntukan tanah yang wakaf yang menyimpang dari akad wakaf; Permasalahan yang terakhir yang sering muncul dalam pengeloalaan tanah wakaf adalah ketidaksesuaian fungsi harta wakaf dengan yang tertera yang ada di akad wakaf atau bisa dikatakan tanah telah beralih fungsi. Penyimpangan semacam ini terjadi karena nazhir beranggapan bebas mengelola wakaf sesuai dengan kehendaknya tanpa mengindahkan akad wakif. Nazhir juga beralasan karena adanya 
permintaan dari masyarakat untuk difungsikan lebih bermanfaat. Sehingga terjadi penyimpangan pengelolaan harta wakaf tidak sesuai dengan yang tertera di akad wakaf.

Mengenai peralihan peruntukan tanah wakaf yang terjadi ada hal yang perlu dilakukan. Pertama, ditinjau mana yang lebih manfaat dalam peruntukan tanah tersebut. Kedua, diadakan musyawarah antara wakif dan nazhir yang disaksikan oleh Pejabat Pembuat Akta Ikrar Wakaf Kecamatan. Ketiga, prosedur peraturan yang ada harus dilaksanakan.

Sesuai dengan Undang-Undang Nomor 41 Tahun 2004 Tentang Wakaf Pasal 40 dan 41 menyebutkan sebagai berikut:

Pasal 40 menyatakan, bahwa harta benda wakaf yang sudah diwakafkan dilarang dijadikan jaminan, disita, dihibahkan, dijual, diwariskan, ditukar atau dialihkan dalam bentuk pengalihan hak lainnya. Kecuali apabila harta benda wakaf yang telah diwakafkan digunakan untuk kepentingan umum sesuai dengan Rencana Umum Tata Ruang (RUTR) berdasarkan ketentuan peraturan perundang-undangan yang berlaku dan tidak bertentangan dengan syari'ah. Dalam proses pelaksanaannya harus memperoleh izin tertulis dari Menteri atas persetujuan Badan Wakaf Indonesia. Harta benda wakaf yang sudah diubah statusnya wajib ditukar dengan harta benda yang manfaat dan nilai tukarnya sekurang-kurangnya sama dengan harta benda wakaf semula.

Menurut Peraturan Pemerintah Nomor 42 Tahun 2006 Tentang Pelaksanaan Undang-Undang Nomor 41 Tahun 2004 Tentang wakaf mengenai pertukaran harta benda wakaf diatur dalam Pasal 49, 50, dan 51 adalah bahwa Perubahan status harta benda wakaf dalam bentuk penukaran dilarang kecuali dengan izin tertulis dari Menteri berdasarkan pertimbangan BWI. Menteri memberikan izin tertulis dengan pertimbangan bahwa perubahan harta wakaf tersebut digunakan untuk kepentingan umum sesuai dengan Rencana Umum Tata Ruang (RUTR) berdasarkan ketentuan Peraturan Perundang-Undangan dan tidak bertentangan dengan prinsip syari'ah, yaitu harta benda wakaf tidak dapat dipergunakan sesuai dengan ikrar wakaf dan dilakukan untuk keperluan keagamaan secara langsung dan mendesak.

Selain pertimbangan di atas, izin pertukaran harta benda wakaf juga dapat diberikan apabila harta benda penukar memiliki sertifikat atau bukti 
kepemilikan sah sesuai dengan Peraturan Perundang-undangan, dan nilai dan manfaatnya sekurang-kurangnya sama dengan harta benda wakaf semula. Adapun mengenai nilai dan manfaat harta benda penukar harus ditetapkan oleh bupati/walikota berdasarkan rekomendasi tim penilai yang anggotanya terdiri dari unsur sebagai berikut:

a. Pemerintah Daerah kabupaten/kota;

b. Kantor Pertanahan kabupaten/kota;

c. Majelis Ulama Indonesia (MUI) kabupaten/kota;

d. Kantor Depatemen Agama kabupaten/kota; dan

e. Nazhir tanah wakaf yang bersangkutan.

Adapun pertimbangan yang diberikan terhadap nilai dan manfaat harta benda penukar yaitu dihitung bahwa harta benda penukar memiliki Nilai Jual Obyek Pajak (NJOP) atau sekurang-kurangnya sama dengan NJOP harta benda wakaf, harta tersebut berada diwilayah yang strategis dan mudah untuk dikembangkan.

Mengenai tata cara penukaran terhadap wakaf yang akan diubah statusnya dilakukan. Pertama, nazhir harus mengajukan permohonan tukar ganti kepada Menteri melalui Kantor Urusan Agama Kecamatan setempat dengan menjelaskan alasan perubahan status/tukar menukar tersebut. Kedua, kemudian Kepala KUA Kecamatan meneruskan permohonan tersebut kepada Kantor Departemen Agama kabupaten/kota. Ketiga, Kepala Kantor Departemen Agama kabupaten/kota setelah menerima permohonan tersebut membentuk tim dengan susunan sebagaimana tersebut di atas yang selanjutnya bupati/walikota setempat membuat Surat Keputusan. Keempat, kemudian Kepala Kantor Departemen Agama kabupaten/kota meneruskan permohonan tersebut dengan dilampiri hasil penilaian dari tim kepada Kepala Kantor Wilayah Departemen Agama Provinsi dan selanjutnya meneruskan permohonan tersebut kepada Menteri. Kelima, setelah mendapatkan persetujuan tertulis dari Menteri, maka tukar ganti dapat dilaksanakan dan hasilnya harus dilaporkan oleh nazhir ke kantor pertanahan dan/atau lembaga terkait untuk pendaftaran lebih lanjut.

Guna menghindari masalah yang timbul dalam pengelolaan wakaf 
di kemudian hari, maka sudah seharusnya dilakukan pengawasan sesuai dengan peraturan perundang-undangan, yaitu sebagaimana diatur dalam Pasal 56 Peraturan Pemerintah Nomor 42 Tahun 2006 Tentang Pelaksanaan Undang-Undang Nomor 41 Tahun 2004 Tentang Wakaf, pemerintah dan masyarakat dapat melakukan pengawasan baik aktif maupun pasif. Pengawasan aktif dilakukan dengan melakukan pemeriksaan langsung terhadap nazhir atas pengelolaan wakaf, sekurang-kurangnya sekali dalam setahun. Sedangkan pengawasan pasif dengan cara melakukan pengamatan atas berbagai laporan yang disampaikan nazhir berkaitan dengan pengelolaan wakaf. Dalam melaksanakan pengawasan tersebut pemerintah dan masyarakat dapat meminta bantuan jasa akuntan publik independen.

Secara lebih rinci, Kompilasi Hukum Islam ${ }^{26}$ menjelaskan masalah pengawasan ini dalam Pasal 227, yaitu bahwa Pengawasan terhadap pelaksanaan tugas dan tanggung jawab nazhir dilakukan bersama-sama oleh Kepala Kantor Urusan Agama Kecamatan, Majelis Ulama Kecamatan, dan Pengadilan Agama yang mewilayahinya.

Langkah pengawasan sebagaimana tersebut di atas diharapkan dapat meminimalisir permasalahan yang timbul, sehingga wakaf dapat berfungsi sebagaimana tujuan wakaf. Namun jika terjadi permasalahan maka lebih didahulukan jalan musyawarah yang tentunya menghasilkan sebuah keputusan yang tepat yang tentunya sangat berguna bagi masyarakat/umat.

\section{Optimalisasi Fungsi Sosial Wakaf dan Implikasinya terhadap Peningkatan Taraf Hidup Masyarakat di Kabupaten Demak}

Wakaf merupakan ibadah sosial yang mempunyai aspek ketaatan manusia kepada Allah juga mempunyai aspek sosial. Wakaf merupakan lembaga sosial Islam yang mempunyai tujuan untuk meningkatan kesejahteraan masyarakat umat Islam. Melihat tujuan tersebut tentunya wakaf diharapkan mampu berimplikasi terhadap peningkatan perekonomian khususnya perekonomian masyarakat di Kabupaten Demak.

\footnotetext{
${ }^{26}$ Lihat selengkapnya Inpres Nomor 1 Tahun 1991 Tentang Kompilasi Hukum Islam.
} 
Kabupaten Demak yang penduduknya berjumlah 1.117.901 (Satu juta seratus tujuhbelas Sembilan ratus satu) jiwa yang terbagi dalam 553.876 laki-laki dan 564.025 perempuan, dengan pemeluk agama Islam berjumlah 1.109.489, dan sekitar 14.06 persen atau berkisar 315.570 jiwa didalam garis kemiskinan. ${ }^{27}$ Maka jika dikalkulasi secara prosentase akan didapati sebuah kesimpulan bahwa penduduk Kabupaten Demak yang berada di dalam garis kemiskinan adalah mayoritas beragama Islam. Angka tersebut tentunya cukup besar dan ironi jika dilihat dari jumlah tanah wakaf yang terdapat di Kabupaten Demak sebagaimana tertera dalam tabel di bawah ini: $:^{28}$

\begin{tabular}{cccc}
\hline No & STATUS WAKAF & JUMLAH BIDANG & LUAS $\left(\mathbf{M}^{2}\right)$ \\
\hline 1 & Belum ada AIW & 86 & 80.060 \\
\hline 2 & Sudah ada AIW & 2097 & 7.310 .435 \\
\hline 3 & Sedang diproses di BPN & 3 & 2.250 \\
\hline 4 & Telah bersertifikat & 3887 & 9.410 .436 \\
\hline & JUMLAH & $\mathbf{6 0 7 3}$ & $\mathbf{1 6 . 8 0 3 . 1 8 1}$ \\
\hline
\end{tabular}

Maka keadaan tersebut harus menjadi perhatian bersama antara Pemerintah Daerah dengan lembaga yang menangani wakaf untuk mencari solusi penanggulangannya, salah satunya dengan memberdayakan wakaf. Keberadaan wakaf sebagai salah satu penunjang perekonomian masyarakat diharapkan mampu menanggulangi masalah perekonomian umat Islam.

Selama ini wakaf di Kabupaten Demak baik di daerah perkotaan, pesisir maupun pedalaman semuanya dalam bentuk sawah dan karas. yang sebagian didirikan gedung-gedung untuk lembaga pendidikan,

${ }^{27}$ Data BPS Kabupaten Demak dalam Angka Tahun 2016.

${ }^{28}$ Data Kantor Penyelenggaraan Zakat dan Wakaf Departemen Agama Kabupaten Demak sampai dengan tahun 2016. 
pondok pesantren, tempat ibadah (masjid dan mushola), dan tempat untuk organisasi keagamaan. Sedangkan sawah kebanyakan disewakan kepada penduduk dengan sistem sewa pertahun atau digarap sendiri oleh nazhir, hasilnya dipergunakan untuk pengembangan bangunan masjid dan tempat-tempat lain yang berkaitan dengan wakaf. Hal ini jelas faktor sosial dari wakaf itu sendiri tidak tersentuh sama sekali. Apalagi melihat kenyataan yang ada, hampir tanah wakaf di daerah pesisir dan pedalaman, sangat tidak produktif dan kebanyakan pula yang terbengkalai dan tidak terurus dengan baik.

Wakaf seharusnya berimplikasi pada perekonomian masyarakat, tetapi di Kabupaten Demak sendiri implikasi wakaf terhadap perekonomian masyarakat masih dirasakan sangat kurang. Karena wakaf masih berbentuk sawah dan karas yang hanya bisa dinikmati oleh masyarakat sekitar tempat tanah wakaf berada. Seharusnya lembaga yang menangani wakaf harus lebih jeli melihat permasalahan wakaf yang ada, Profesionalisme sangat dibutuhkan agar wakaf bisa berkembang dan fungsi sosialnya bisa di optimalkan yang akan berimplikasi pada peningkatan kesejahteraan taraf hidup masyarakatnya, mereka juga harus lebih inovatif mengelola wakaf dalam bentuk yang lain, seperti wakaf tunai/uang.

Wakaf tunai yang seharusnya dan sangat diharapkan dapat membantu masyarakat dalam mengatasi masalah perekonomian pada kenyataannya di kabupaten Demak belum terealisasi sama sekali. Alasannya, pertama mayoritas wakif belum mengetahui prosedur wakaf tunai. Kedua mereka rata-rata takut uangnya tidak akan tersalurkan kepada yang tempat yang tepat untuk menerima. Ketiga mereka hanya tahu bahwa wakaf adalah dalam bentuk tanah. ${ }^{29}$

Sama halnya pendapat Mukhlisin, selaku Kepala Penyelenggara Zakat dan Wakaf Kantor Urusan Agama Kecamatan Bonang. Beliau mengatakan belum terealisasinya wakaf tunai di kabupaten Demak khususnya di daerah pesisir karena masyarakat selalu beranggapan, pertama wakaf yang berupa tanah maka akan selalu mendapatkan pahala selama tanah tersebut masih digunakan. Kedua wakaf berupa uang maka akan habis

${ }^{29}$ Wawancara dengan Ahmad Munif, Tokoh Agama Demak, 2 Juni 2016. 
ketika uang tersebut digunakan. Ketiga wakaf berupa uang lebih dominan untuk bisa dikorupsi ${ }^{30}$

Solusi yang tepat untuk mengatasi permasalahan tersebut adalah dengan mengoptimalkan pengelolaan dan fungsi sosial wakaf yang akan menjadikan wakaf lebih produktif. Salah satu wujud atau bentuk produktifitas wakaf adalah dengan memberdayakan wakaf tunai sebagai problem solving yang tepat, terlebih dalam kondisi masyarakat yang sangat membutuhkan bantuan di bandingkan wakaf tanah yang hasilnya tidak jelas. Sulitnya lapangan kerja menjadikan sulitnya masyarakat mengatasi masalah perekonomian. Sehingga mereka memerlukan uluran bantuan modal untuk menciptakan atau mengembangkan usahanya. Di sinilah lembaga-lembaga wakaf seharusnya lebih tanggap terhadap permasalahan masyarakat dalam bidang ekonomi. Mereka sudah sepatutnya berpikir tentang wakaf yang lebih berguna dan dirasakan sangat membantu dalam peningkatan kesejahteraan ekonomi masyarakat. Dan wakaf tunai atau uang ternyata sangat bermanfaat dalam kondisi yang seperti sekarang ini, karena wakaf uang ternyata tidak hanya sekedar mampu meningkatkan pertumbuhan ekonomi, namun juga mampu menciptakan pemerataan pendapatan, terutama bagi masyarakat yang semula tidak memiliki peluang usaha menjadi memiliki peluang usaha, dan bagi masyarakat yang semula tidak memiliki pendapatan menjadi memiliki pendapatan.

Melihat cukup besarnya masyarakat di negara Indonesia umumnya dan khususnya Kabupaten Demak yang notabene beragama Islam dan tidak maksimalnya fungsi wakaf yang ada dalam peningkatan kesejahteraan ekonomi masyarakat, maka sudah seharusnya lembaga yang menangani wakaf harus melakukan langkah-langkah sebagai berikut: ${ }^{31}$

1. Membangkitkan sektor usaha kecil dan menengah dengan memberikan modal usaha kepada para petani, petambak, nelayan,

${ }^{30}$ Wawancara dengan Mukhlisin, Kepala Penyelenggara Zakat dan Wakaf Kantor Urusan Agama Kecamatan Bonang, 24 Juni 2016.

${ }^{31}$ Departemen Agama, Wakaf Tunai dalam Perspektif Hukum Islam (Jakarta: Depag RI, 2005), h. 31. 
pedagang kecil dan menegah. Pada setiap bulannya masyarakat harus memberikan keuntungan kepada pengelola wakaf, yang kemudian keuntungan tadi bisa digunakan untuk memberikan modal kepada masyarakat lainnya. Pengelola wakaf juga bisa melakukan terobosan dengan hasil yang diperoleh dari wakaf yang dikelola yaitu dengan cara mendirikan home industry, atau pabrik yang tentunya akan lebih membantu mengurangi pengangguran. Dengan mendirikan home industry dan perusahaan maka secara otomatis akan membantu perekonomian masyarakat tidak hanya di wilayah sekitarnya namun bisa terjadi pemerataan perekonomian. Dengan begitu wakaf yang tadinya sama sekali tidak berimplikasi terhadap perekonomian masyarakat di Kabupaten Demak dengan adanya terobosan tersebut secara otomatis akan berimplikasi terhadap perekonomian masyarakat.

2. Pengelola wakaf dengan hasil wakaf yang dikelolanya juga bisa menyertakan modal kepada usaha kecil menengah, dalam hal ini pengelola tidak memberikan modal keseluruhan kepada masyarakat, melainkan hanya menyertakan modal atau investasi kepada usaha kecil menengah untuk bisa mengembangkan usahanya. Seperti menyertakan modal kepada masyarakat nelayan yang mempunyai toko peralatan nelayan, atau pedagang kelontong. Dengan modal yang diterimanya diharapkan usaha mereka bisa berkembang dan tentunya akan membuka peluang kerja bagi masyarakat sekitarnya.

3. Pengelola wakaf dapat mengoptimalkan tanah wakaf yang ada dengan cara di tanah wakaf tersebut didirikan bangunan seperti ruko, mal atau bangunan lain yang mempunyai nilai ekonomis kemudian disewakan kepada para pengusaha. Dari hasil usaha tersebut pengelola bisa mendapat kembali modal pokoknya disertai keuntungan yang kemudian dari keuntungan tersebut bisa digunakan untuk membantu masyarakat lainnya. Selain itu pengelola wakaf bisa membuka lapangan kerja baru bagi masyarakat yang membutuhkan sehingga secara tidak langsung sangat membantu dalam peningkatan perekonomian masyarakat. Sesuai dengan pendapat M. Nur Samad Kamba, atase pendidikan dan kebudayaan 
KBRI Kairo, mengungkapkan bahwa setiap musim haji, Arab Saudi memerlukan sekitar tiga juta domba, sedangkan kebutuhan keseluruhan mencapai 10 juta ekor domba lebih. Selama ini dombadomba tersebut diimpor dari Selandia Baru, Swis dan Swedia. Lalu bagaimana jika tanah wakaf yang ada di Indonesia didayagunakan untuk pengembangan domba?. Menurut perhitungan Nur Samad, untuk memelihara lima ekor domba memerlukan satu orang tenaga kerja. Sebuah perusahaan yang memelihara 200 ribu ekor domba membutuhkan sedikitnya 400 ribu tenaga kerja. Jadi kalau total tiga juta ekor domba bisa menyerap tenaga kerja tak kurang dari 600 ribu. Ini merupakan lahan lapangan kerja yang luar biasa di saat banyaknya Pemutusan Hubungan Kerja. Maka secara otomatis selain bisa menciptakan lapangan kerja baru juga sangat membantu dalam peningkatan ekonomi masyarakat.

4. Pengelola wakaf juga bisa berperan sebagai pengusaha yang membelikan peralatan yang dibutuhkan masyarakat seperti peralatan pertanian, peralatan untuk nelayan dan peralatan lain yang dibutuhkan masyarakat dalam bekerja dengan cara pembayaran diangsur. Dengan cara ini masyarakat sangat diuntungkan dan dibantu karena merasa teringankan bebannnya sehingga mereka bisa mengembangnkan usahanya begitu juga pengelola wakaf dapat mendapat keuntungan dari penjualan tersebut.

Dari uraian di atas seharusnya pengelola wakaf harus lebih berani berinovasi jangan hanya terpaku dengan harta yang ada. Melainkan membuat terobosan baru di bidang wakaf yaitu dengan mengelola wakaf lebih produktif salah satunya dengan pengembangan wakaf tunai/ uang yang tentunya manfaatnya tidak hanya dirasakan oleh masyarakat setempat melainkan bisa terjadi pemerataan, maksudnya masyarakat di daerah lainpun bisa ikut merasakan manfaatnya.

\section{Penutup}

Kedudukan hukum tanah wakaf di kabupaten Demak sebelum berlakunya Undang-Undang Nomor 41 Tahun 2004 Tentang wakaf masih di bawah tangan. Hal ini dikarenakan pelaksanaan ikrar wakaf 
masih bersifat konvensional dengan prinsip kepercayaan terhadap tokoh agama atau tokoh masyarakat yang dianggap kredibel dan mampu tanpa melihat kualitasnya. Sehingga sangat riskan terhadap munculnya problematika yang bisa mengakibatkan wakaf tidak maksimal bahkan tidak jelas keberadaannya.

Pelaksanaan pengesahan tanah wakaf di Kabupaten Demak setelah lahirnya Undang-Undang Nomor 41 Tahun 2004 Tentang Wakaf terbagi dalam dua kategori, yaitu pengesahan tanah wakaf baru dan tanah wakaf lama. Kedua proses pengesahan tersebut akan menjadikan tanah wakaf jelas legalitasnya dan aman kedudukannya. Sehingga dapat meminimalisir permasalahan-pemasalahan yang timbul di kemudian hari.

Optimalisasi pengelolaan dan fungsi sosial wakaf di Kabupaten Demak belum bisa berjalan sebagaimana fungsinya. Hal ini disebabkan selama ini wakaf di Kabupaten Demak baik di daerah perkotaan, pesisir maupun pedalaman keseluruhan wakaf masih dalam bentuk sawah dan karas yang sebagian didirikan gedung-gedung untuk tempat pendidikan, pondok pesantren dan tempat ibadah. Sedangkan sawah kebanyakan disewakan kepada penduduk dengan sistem sewa pertahun, hasilnya dipergunakan untuk pengembangan bangunan masjid dan tempat-tempat lain yang berkaitan dengan wakaf. Sehingga wakaf belum berimplikasi pada perekonomian masyarakat. Maka perlu pemberdayaan wakaf produktif yang dapat menekan terhadap pengelolaan dan pengoptimalan fungsi sosial wakaf yang bernilai ekonomis, dapat menunjang dalam peningkatan taraf hidup masyarakat. Perlu profesionalisme pengelola yang mampu memberdayakan produktifitas wakaf dengan berbagai inovasi baru, salah satunya dengan mengembangkan wakaf tunai/uang di Kabupaten Demak. Dengan pemberdayaan wakaf tunai/uang diharapkan bisa lebih menekankan pada pengelolaan dan mengoptimalkan fungsi sosial wakaf yang akan berimplikasi pada kesejahteraan ekonomi masyarakat Islam di Kabupaten Demak.

\section{Pustaka Acuan}

Anshori, Abdul Ghofur. Hukum dan Praktik Perwakafan di Indonesia, Cet. II. Yogyakarta: Pilar Media, 2006. 
Asni. "Pengembangan Hukum Perwakafan di Indonesia." Jurnal Al-'Adl 7, no. 2 (Juli 2014): 5.

Dahliana, Ike Natalia. "Tinjauan Yuridis Terhadap Legalitas Tanah Wakaf yang Belum Disertifikatkan di Kota Samarinda." Jurnal Prediksi 7 , no. 8 (Februari 2009): 48-49.

“Data BPS Kabupaten Demak dalam Angka Tahun 2016”.

"Data Kantor Badan Pertanahan Nasional Kabupaten Demak tahun 2016".

"Data Kantor Penyelenggaraan Zakat dan Wakaf Departemen Agama Kabupaten Demak sampai dengan tahun 2016".

Djalaludin Ahmad, "Legitimasi Fiqih Bagi Obtimalisasi dan Pendayagunaan Wakaf”, Iqtishoduna: Jurnal Ekonomi dan Bisnis Islam 3, No. 1, (2007).

Djanggih, Hardianto, and Salle Salle. "Aspek Hukum Pengadaan Tanah bagi Pelaksanaan Pembangunan untuk Kepentingan Umum.” Pandecta: Research Law Journal 12, no. 2 (2018).

Departemen Agama. Paradigma Baru Wakaf di Indonesia, Ditbang Zakat dan Wakaf Dirjen Bimas Islam dan Gara Haji. Jakarta: Depag I, 2004.

Departemen Agama. Wakaf Tunai dalam Perspektif Hukum Islam. Jakarta: Depag RI, 2005.

Departemen Agama RI. Al Qur'an dan Terjemahannya. Semarang: Yayasan Penyelenggara Penterjemah Al-Qur'an, Al Waah, 1995.

Fetrimen. "Pemberdayaan Asset Tanah Wakaf dan Non Wakaf Sebagai Sarana Pendidikan di pimpinan Wilayah Muhammadityah Jambi." Jurnal Ekonomi Islam 7, no. 2 (September 2016): 58.

Koeswahyono, Imam. "Penyelesaian Persoalan Tanah Perkebunan dalam Perspektif Socio Legal (Studi Pada Beberapa Perkebunan di Jawa Timur)." Jurnal Hukum \& Pembangunan 38, no. 4 (2008): 525-555.

Munir, Ahmad Sirojudin. "Optimalisasi Pemberdayaan Wakaf Secara Produktif.” Ummul Qura 6, no. 2 (September 2018): 102.

Nasution, M. "Hutan dan Persoalan Tanah Ulayat." Roundtable Discussion on Indigenous Peoples' Property Rights held by the Indonesian Human Rights Commission 24 (1999). 
Peraturan Menteri Agraria No 3 Tahun 1997 Tentang Peraturan Pelaksanaan Peraturan Pemerintah Nornor 24 Tahun 1997 Tentang Pendaftaran Tanah.

Peraturan Pemerintah Nornor 24 Tahun 1997 Tentang Pendaftaran Tanah.

Peraturan Pemerintah No 46 Tahun 2002 Tentang Biaya Pengurusan Pelayanan Pertanahan.

Peraturan Pemerintah Nomor 42 Tahun 2006 Tentang Peraturan Pelaksanaan Undang-Undang Nomor 41 Tahun 2004 Tentang Wakaf.

Qodin, Junaidi Abdullah Nur. "Penyelesaian Sengketa Wakaf dalam Hukum Positif." Jurnal Ziswaf 1, no. 1 (Juni 2014): 39.

Rahmi, Elita. "Tarik Menarik Antara Desentralisasi dan Sentralisasi Kewenangan Pemerintah Daerah dalam Urusan Pertanahan.” Jurnal Hukum Ius Quia Iustum 16 (2009).

Rosyid, Moh. "Peran Sertifikat Tanah Wakaf dalam Mengantsipasi Dinamika Zaman: Studi Kasus Madrasah Diniyah Muawanatul Muslimin di Kudus." Jurnal Ziswaf 3, no. 1 (Juni 2016): 107.

Syauqi, Muhammad Alfin. "Optimalisasi Pengelolaan Wakaf Uang Untuk Kesejahteraan Umum.” Jurnal Kanun Ilmu Hukum 63, no. 16 (Agustus 2014): 372.

Tim Redaksi Nuansa Aulia. Kompilasi Hukum Islam (Hukum Perkawinan, Kewarisan, dan Perwakafan). Bandung: CV. Nuansa Aulia, 2008.

Undang-Undang Nomor 41 Tahun 2004 Tentang Wakaf.

Undang-Undang Nomor 5 Tahun 1960 Tentang Peraturan Dasar Pokokpokok Agraria.

Inpres Nomor 1 Tahun 1991 Tentang Kompilasi Hukum Islam.

Winoto, Joyo. "Reforma Agraria: Mandat Politik, Konstitusi dan Hukum dalam Rangka Mewujudkan Tanah untuk Keadilan dan Kesejahteraan Rakyat." Paper. Delivered in General Lecture in Gajah Mada University. Yogyakarta 22 (2007). 


\section{Wawancara}

Ahmad Anas, Kepala Kantor Urusan Agama Kecamatan Demak, 27 Mei 2016.

Ahmad Munif, Tokoh Agama Demak, 2 Juni 2016.

Lasdi, Kepala Bagian Pendaftaran Dan Informasi Badan Pertanahan Nasional Kabupaten Demak, 1 Juli 2016.

Masrohan, Kepala Kantor Urusan Agama Kecamatan Kebonagung, 29 Juni 2016.

Sholikhul Hadi, Kepala Kantor Urusan Agama Kecamatan Bonang, 17 Juni 2016.

Mukhlisin, Kepala Penyelenggara Zakat dan Wakaf Kantor Urusan Agama Kecamatan Bonang, 24 Juni 2016.

Nur Ali, Kepala Penyelenggara Zakat dan Wakaf Kantor Urusan Agama Kecamatan Kebonagung, 30 Juni 2016. 